\title{
Divergent movements of walrus and sea ice in the northern Bering Sea
}

\author{
Chadwick V. Jay ${ }^{1, *}$, Mark S. Udevitz ${ }^{1}$, Ron Kwok ${ }^{2}$, Anthony S. Fischbach ${ }^{1}$, \\ David C. Douglas ${ }^{3}$
}

${ }^{1}$ US Geological Survey, Alaska Science Center, 4210 University Drive, Anchorage, Alaska 99508, USA

${ }^{2}$ Jet Propulsion Laboratory, California Institute of Technology, 4800 Oak Grove Drive, Pasadena, California 91109, USA

${ }^{3}$ US Geological Survey, Alaska Science Center, 3100 National Park Road, Juneau, Alaska 99801, USA

\begin{abstract}
The Pacific walrus Odobenus rosmarus divergens is a large Arctic pinniped of the Chukchi and Bering Seas. Reductions of sea ice projected to occur in the Arctic by mid-century raise concerns for conservation of the Pacific walrus. To understand the significance of sea ice loss to the viability of walruses, it would be useful to better understand the spatial associations between the movements of sea ice and walruses. We investigated whether local-scale ( 1 to $100 \mathrm{~km})$ walrus movements correspond to movements of sea ice in the Bering Sea in early spring, using locations from radio-tracked walruses and measures of ice floe movements from processed synthetic aperture radar satellite imagery. We used generalized linear mixed-effects models to analyze the angle between walrus and ice floe movement vectors and the distance between the final geographic position of walruses and their associated ice floes (displacement), as functions of observation duration, proportion of time the walrus was in water, and geographic region. Analyses were based on 121 walrus-ice vector pairs and observations lasting 12 to $36 \mathrm{~h}$. Angles and displacements increased with observation duration, proportion of time the walrus spent in the water, and varied among regions (regional mean angles ranged from $40^{\circ}$ to $81^{\circ}$ and mean displacements ranged from 15 to $35 \mathrm{~km}$ ). Our results indicated a lack of correspondence between walruses and their initially associated ice floes, suggesting that local areas of walrus activities were independent of the movement of ice floes.
\end{abstract}

KEY WORDS: Pacific walrus · Odobenus rosmarus $\cdot$ Bering Sea $\cdot$ Sea ice $\cdot$ Telemetry $\cdot$ RADARSAT RGPS $\cdot$ SAR

\section{INTRODUCTION}

The Pacific walrus (Odobenus rosmarus divergens) is a large Arctic pinniped that forages on the seafloor of the continental shelves of the Chukchi and Bering Seas. The species is a vital subsistence resource to coastal communities in Alaska and Russia (Metcalf \& Robards 2008) and can substantially affect the structure of benthic communities (Oliver et al. 1983, Oliver et al. 1985, Nelson \& Johnson 1987, Nelson et al. 1987, Nelson et al. 1994, Born et al. 2003, Ray et al. 2006).

Sea ice is used by walruses as a platform for giving birth, nursing young, molting, resting between feeding forays, accessing offshore foraging areas, and avoiding nearshore predation and disturbance (Fay 1982). The large losses of sea ice that are projected to occur in the Arctic by mid-century (Maslanik et al. 2007, Overland \& Wang 2007, Stroeve et al. 2007, Wang \& Overland 2009) raise concerns for the conservation of the Pacific walrus and is the basis of a recent non-governmental petition to the US Fish and Wildlife Service to list the Pacific walrus population as threatened or endangered under the US Endangered Species Act. To understand the significance of sea ice loss to the viability of walruses, it would be useful to better understand the spatial associations between the movements of sea ice and walruses. Broad-scale seasonal associations are known (Fay 1982), but local within-season associations are poorly understood. 
Seasonal movements of sea ice over the Chukchi and Bering Seas allow walruses to occupy a wide area over the continental shelf during the year. Walruses typically occur in areas of unconsolidated ice, open leads, and thin ice where they can create breathing holes (Burns et al. 1980, 1981, Fay 1982). In winter, the entire Pacific walrus population resides in the Bering Sea, and it is here on the sea ice that breeding courtships (January to February) and most of the calving (April to June) occur. Most adult female and young walruses prefer to use sea ice for hauling out throughout the year. In spring, they follow the receding ice pack northward to summer in the Chukchi Sea. Unlike females, most adult male walruses summer near coastal areas of the Bering Sea, using land haul-outs to rest between foraging trips. In autumn, the female and young walruses in the Chukchi Sea migrate with the developing sea ice southward into the Bering Sea, where they are joined in late autumn and winter by the males that summered there (Fay 1982, Jay \& Hills 2005).

The Bering Sea has relatively steady-state sea ice conditions in winter until the disintegration and northward retreat of sea ice in spring (Burns et al. 1981). Regions of relatively homogeneous ice habitats are formed each year in the Bering Sea from regionally specific winds, currents, and land configurations (Muench \& Ahlnas 1976, Burns et al. 1980, 1981). St. Lawrence Island is a major land form affecting movements of ice in the northern Bering Sea. Most of the ice in this region forms in the northern Bering Sea, but some originates from the Chukchi Sea. The ice is driven southward by northerly winds from November to December until mid- to late April (Burns et al. 1981). In winter, winds from the north and northeast prevail about $60 \%$ of the time, typically with speeds near $10 \mathrm{~m}$ $\mathrm{s}^{-1}$. The northerlies compress ice floes against the north side of St. Lawrence Island, and create a polynya on the island's south side. The polynya can extend along nearly the entire $150 \mathrm{~km}$ length of the island and as much as $25 \mathrm{~km}$ offshore (Danielson et al. 2006), and is associated with high benthic production (Grebmeier \& Cooper 1995). As the ice is pushed southward, it is deflected around the narrower passages of the east and west sides of the island where the ice is compressed and deformed. The ice diverges as it moves farther south and into the wider parts of the Bering Sea. There are periods of northward ice drift during winter and early spring, but they are of short duration. Late spring is characterized by melting ice and the northward retreat of sea ice with rising air temperatures (Burns et al. 1981).

Burns et al. (1980) delineated 4 regions of marine mammal ice habitats around St. Lawrence Island based on major features of March-April ice cover. These are (1) a region north of the island characterized by a com- pact mass of heavy, pressure-ridged ice extending northward for $>100 \mathrm{~km} ;(2)$ a region south of the island characterized by broken to rounded pack ice, usually with a well developed polynya; (3) a region east of the island characterized by continuous ice, most often consisting of pack ice and broken pack ice with leads and angular floes, and with heavy ice occupying $>85 \%$ of the surface; and (4) a region west of the island characterized by broken, rounded, or loose ice, often associated with open water or thin ice, and often lacking heavy ice. Ice to the south, east, and west of the island is usually active and forming new leads.

Although walrus movements are determined by the movement of sea ice when they are hauled out on the ice, their movements in water may be affected by water currents, which are also regionally variable. The general flow of water through the Bering Sea is northward from the North Pacific towards the Arctic Ocean. The flow is intensified in the areas northwest, north, and east of St. Lawrence Island, with average speeds of $\sim 20 \mathrm{~cm} \mathrm{~s}^{-1}$ along Anadyr Strait to the northwest and 10 to $15 \mathrm{~cm} \mathrm{~s}^{-1}$ along Shpanberg Strait to the east (Danielson et al. 2006). To the south of the island, 3 bands of currents have been described. One is a nearshore band extending out to $\sim 60$ to $70 \mathrm{~km}$, flowing eastward or southeastward at $\sim 5 \mathrm{~cm} \mathrm{~s}^{-1}$; the second is a transitional band extending out about another $100 \mathrm{~km}$ from the nearshore band, with a northward, but weak flow of $<2$ $\mathrm{cm} \mathrm{s}^{-1}$; and the third is an outer band over the central shelf out to at least mid-way between St. Lawrence and St. Matthews Islands with a westward or northwestward flow of 5 to $10 \mathrm{~cm} \mathrm{~s}^{-1}$ (Danielson et al. 2006).

Walrus movements throughout the year are likely to be associated with particular activities, including breeding, socialization, predator avoidance, migration, foraging, and traveling between foraging areas. We investigated whether local-scale ( 1 to $100 \mathrm{~km})$ walrus movements correspond to movements of sea ice in the Bering Sea in early spring, using location data from radio-tracked walruses and measures of ice floe movements from processed synthetic aperture radar satellite imagery. A lack of correspondence would suggest that areas of walrus activity are not dependent on the movement of ice at this scale. Further, we test whether local correspondence of walrus-ice movements varied among regions that have been recognized by others as having unique ice types and movement patterns (Burns et al. 1980, 1981).

\section{MATERIALS AND METHODS}

Walrus tracking. Forty adult walruses were tracked with satellite-linked radio-tags (hereafter referred to as 'tags') (Telonics) in the northern Bering Sea as part 
of an abundance survey conducted in spring 2006. The tags were similar to the post-type tags described in Jay et al. (2006) and were deployed with a crossbow from a distance of $\sim 10 \mathrm{~m}$. Each tag was fitted with a barbed head that embedded in the walrus's blubber layer on impact. We attempted to place each tag on the individual's dorsum, midway between the shoulders.

We deployed tags opportunistically as walrus groups were encountered, while attempting to distribute tags as widely as possible among walruses within the tagging region south of St. Lawrence Island. Our deployment technique involved the targetting of individuals that were lying with their back to the approaching tagging team, and that could be approached from downwind and without obstruction from neighboring walruses. The barbed heads were too large for the thin skin and blubber layers of young animals (Jay et al. 2006), so we deployed tags on adult walruses, except parturient females. Selections were also tempered by daily weather and ice conditions and overall availability of walruses. In most cases, the sex of tagged walruses was classified either from sexually dimorphic features (Fay 1982, Fay \& Kelly 1989), or genetic determination of sex from remotely collected biopsies (Fischbach et al. 2008). If neither of these methods successfully determined sex, the animal was classified as undetermined sex.

Haul-out chronologies from tagged walruses were derived from data collected by a conductivity sensor on the walrus's tag. The conductivity sensor detected whether the tag was in or out of salt water. Conductivity was measured every second and the results were summarized over 30 min intervals. If $\geq 90 \%$ of the measurements for a given interval indicated the tag was out of water, the walrus was classified as being hauled out during that interval.

Tags had battery capacities that allowed transmissions for at least 3 to 4 weeks. Transmissions were suspended whenever the tag was submerged to conserve battery life. Information from 232 consecutive $30 \mathrm{~min}$ behavioral intervals was encoded in each transmission. Thus, the data from any given behavioral interval were received if there was at least one successful transmission during the $4.8 \mathrm{~d}(116 \mathrm{~h})$ period while this information was stored onboard the tag. This provided considerable redundancy and allowed for collection of a nearly continuous record of haul-out behavior. We only retained data from transmissions that passed a checksum test designed to identify transmission errors.

Records of haul-out data were received and geographic locations of tagged walruses were estimated by the Argos location and data collection system (Collecte Localisation Satellites 2007). Because these locations are subject to errors, they were filtered, using the Douglas Argos Filter (Douglas 2006), to retain only those locations with spatial errors expected to average $<\sim 5 \mathrm{~km}$. This filter assesses the plausibility of locations based on spatial redundancy, Argos location quality, maximum rate of movement, and turning angles of successive movements. We set the algorithm to retain (1) all standard class locations, (2) non-standard class locations within $2 \mathrm{~km}$ of the previous or subsequent location, and (3) remaining locations based on a distance-angle-rate filter that accepted a maximum walrus speed of $10 \mathrm{~km} \mathrm{~h}^{-1}$ and rejected locations at the apex of highly acute angles (RATECOEF $=25$, Douglas 2006). Other marine animal tracking studies have used the same algorithm, but with different user-defined settings (Andrews et al. 2008, Eckert et al. 2008), or an algorithm with a very similar approach (Freitas et al. 2008). Despite a lack of evidence that tagging alters the animal's behavior, we elected to exclude all data from the first $24 \mathrm{~h}$ after deployment of each tag in case there was any short-term effect of the tagging procedure.

Linking walrus and ice movements. Daily synthetic aperture radar (SAR) images of the Bering Sea, coincident with areas and times of the walrus tracking data, were acquired from NASA through the University of Alaska Fairbanks, Alaska Satellite Facility. The SAR imagery was processed with the RADARSAT Geophysical Processor System (RGPS) at the Jet Propulsion Laboratory, California, to produce motion vectors for individual ice floes by tracking common image features (<150 m location error) (Kwok 1998).

Successive walrus locations were usually acquired within a few hours of one another (85th percentile of time between locations $=3 \mathrm{~h}$ ), whereas RADARSAT images were acquired at $\sim 12 \mathrm{~h}$ intervals $( \pm 2 \mathrm{~h})$. We used the following procedure to obtain a set of walrus-ice vector pairs for analysis. We identified each of as many walrus locations as possible associated with an underlying ice floe within $\sim 12 \mathrm{~h}$ of the walrus location that could be distinguished and tracked through at least one subsequent RADARSAT image. Each match constituted the start of a walrus-ice vector pair. The ice floe was followed through as many subsequent RADARSAT images as possible. The ice floe in the last image defined the location and time for the end of the ice vector, and the walrus's location closest in time to the end of the ice vector defined the location and time for the end of the walrus vector. We selected for our analysis only those vector pairs where the difference in time between the walrus and ice start times, and between the walrus and ice end times, were within $10 \%$ of the duration of the ice vector. We refer to the tracked ice floe as the walrus's initially associated ice floe.

Analysis. We used 2 statistics to characterize the relation between the walrus and ice vectors in each 
pair: the internal angle formed by the 2 vectors (hereafter referred to as 'angle') and the distance between the end points of the 2 vectors (hereafter referred to as 'displacement'). Also, for each walrusice vector pair, we estimated the proportion of time the walrus was in water from its associated haul-out chronology (hereafter referred to as 'walrus time-inwater').

In addition, we investigated the possibility of differences in the correspondence of walrus-ice movements among regions of ice habitat in the northern Bering Sea that were identified by Burns et al. (1980). Most of our walrus-ice vector pairs fell within, or near to, 4 of these regions around St. Lawrence Island, and we assigned each vector pair to one of the 4 regions based on the pair's start location, except for 10 pairs, as described below (Fig. 1). We recognize that ice habitat boundaries probably shifted during our study with wind reversals and as the region transitioned from cold and consistent ice conditions in very early spring to more dynamic melting ice conditions in late spring. Five walrus-ice vector pairs were slightly north of the western region and were assigned to that region (Fig. 1). We assigned 5 vector pairs that were outside the boundaries of the eastern region to that region

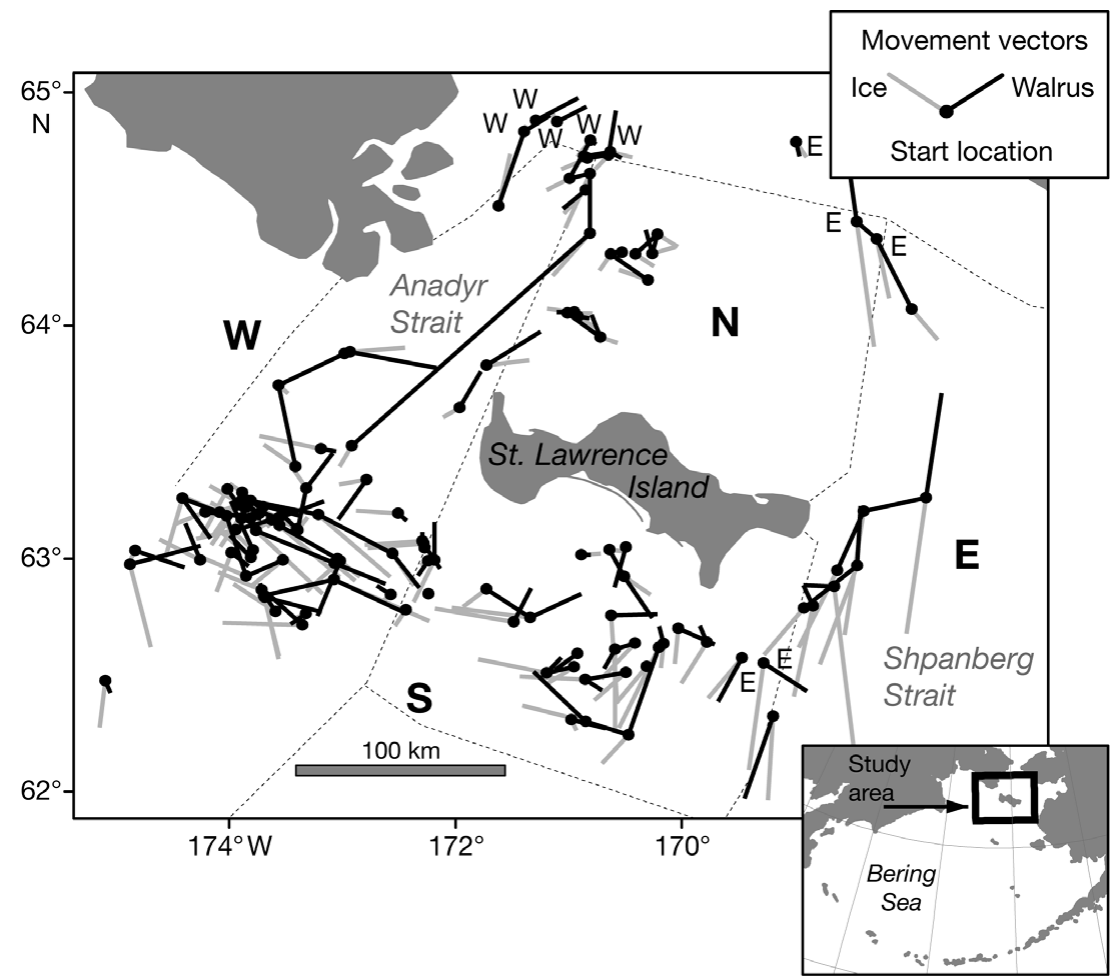

Fig. 1. Odobenus rosmarus divergens. Walrus-ice vector pairs derived from walrus and ice movements observed in 4 regions of the northern Bering Sea $(\mathbf{N}$, S, E, W: north, south, east, west regions, respectively; delineated by Burns et al. 1980), 26 March to 10 May 2006. Small 'W's and 'E's indicate vector pairs that were re-assigned to a region (see: 'Materials and methods: Analysis') because the ice vectors and locations from these pairs appeared to be most closely associated with the region's character of having a high rate of southward ice motion around the eastern side of St. Lawrence Island (Burns et al. 1980).

We used generalized linear mixed-effects models (McCullagh \& Nelder 1999, Littell et al. 2006) to model angles and displacements as functions of tracking duration, proportion of walrus time-in-water, and region. We considered Normal, Poisson, and Gamma distributions with canonical links to cover a range of possible variance structures. We used plots of residuals to select the final form of the model (McCullagh \& Nelder 1999). We initially included a random effect for walrus to account for the fact that we had multiple observations for many walruses. We removed this effect from the final model if the estimate of the final variance component associated with this effect had a $95 \%$ confidence interval that included zero. We used Type III F-tests for significance of fixed effects and $95 \%$ confidence intervals for their least-squares means to assess effects of tracking duration, proportion of walrus time-in-water, and region. Separate analyses were conducted for angle and displacement. Finally, we used mean directions and mean resultant lengths (Fisher 1993) to characterize direction of movement for walruses and ice floes in each region.

\section{RESULTS}

Analyses were based on data from 22 walruses (17 female, 4 male, and 1 undetermined) and 121 walrus-ice vector pairs; almost $80 \%$ of the vector pairs were from the southern and western regions (Table 1, Fig. 1). Walrus location estimates were mostly of Argos location quality $B$, and roughly an equal number of location estimates were of quality $A$, 1,2 , and 3 (number of locations per quality type were: 1/Z, 142/B, 24/A, 6/0, 25/1, 25/2, and 19/3). Most vector pair observations were of $36 \mathrm{~h}$ duration (Table 2).

Observations were obtained from 26 March to 10 May 2006 (Fig. 2), which corresponds to a period from very early spring, when most walruses are still within their winter breeding areas, to late spring, when many walruses are migrating with the disintegration of ice. Vast ice fields of variable concentration and thickness were available to wal- 
Table 1. Odobenus rosmarus divergens. Number of walrusice vector pairs derived from walrus and ice movements observed in 4 regions of the northern Bering Sea, 26 March to 10 May 2006

\begin{tabular}{|c|c|c|c|c|c|}
\hline \multirow{2}{*}{$\begin{array}{l}\text { Walrus } \\
\text { Tag no. }\end{array}$} & \multirow[b]{2}{*}{ North } & \multicolumn{2}{|c|}{ Region } & \multirow[b]{2}{*}{ West } & \multirow[b]{2}{*}{ Total } \\
\hline & & South & East & & \\
\hline 7603 & 0 & 2 & 0 & 0 & 2 \\
\hline 7604 & 0 & 4 & 3 & 0 & 7 \\
\hline 7606 & 0 & 3 & 0 & 2 & 5 \\
\hline 7614 & 4 & 0 & 0 & 2 & 6 \\
\hline 10953 & 0 & 0 & 0 & 5 & 5 \\
\hline 10955 & 0 & 0 & 0 & 3 & 3 \\
\hline 10956 & 0 & 1 & 0 & 0 & 1 \\
\hline 10959 & 0 & 1 & 0 & 5 & 6 \\
\hline 10961 & 0 & 1 & 0 & 0 & 1 \\
\hline 10962 & 1 & 0 & 0 & 18 & 19 \\
\hline 10963 & 0 & 0 & 0 & 5 & 5 \\
\hline 62646 & 0 & 0 & 0 & 8 & 8 \\
\hline 62647 & 0 & 1 & 0 & 1 & 2 \\
\hline 62648 & 0 & 0 & 0 & 1 & 1 \\
\hline 62651 & 0 & 1 & 1 & 0 & 2 \\
\hline 62652 & 0 & 2 & 7 & 0 & 9 \\
\hline 62656 & 6 & 0 & 0 & 2 & 8 \\
\hline 62658 & 0 & 5 & 2 & 0 & 7 \\
\hline 62665 & 0 & 1 & 0 & 8 & 9 \\
\hline 62671 & 0 & 1 & 0 & 6 & 7 \\
\hline 62672 & 0 & 5 & 0 & 0 & 5 \\
\hline 62674 & 0 & 2 & 1 & 0 & 3 \\
\hline Total & 11 & 30 & 14 & 66 & 121 \\
\hline
\end{tabular}

Table 2. Odobenus rosmarus divergens. Duration of walrusice vector pair observations in 4 regions of the northern Bering Sea, 26 March to 10 May 2006

\begin{tabular}{|lccc|}
\hline & \multicolumn{3}{c|}{ Duration (h) } \\
\cline { 2 - 4 } Region & 12 & 24 & 36 \\
\hline North & 1 & 1 & 9 \\
South & 6 & 3 & 21 \\
East & 0 & 1 & 13 \\
West & 2 & 18 & 46 \\
Total & 9 & 23 & 89 \\
\hline
\end{tabular}

ruses during this period (National Ice Center, www.natice.noaa.gov). Most walrus-ice vector pairs in the southern region were observed in the first part of the study period, whereas most vector pairs in the eastern region were observed in the latter part of the study period (Fig. 2). Vector pairs in the northern and western regions were observed over a relatively wide time period.

Walruses were in the water $>50 \%$ of the time for most walrus-ice vector pairs (Fig. 3). Vector pair angles ranged from $1^{\circ}$ to $180^{\circ}$ (median $=63^{\circ}$, Fig. 3 ) and vector pair displacements ranged from 1 to $164 \mathrm{~km}$ (median $=17$ km, Fig. 3).

The directions of ice and walrus movements were highly variable, but showed tendencies within regions (Fig. 4). In the northern region, ice tended to flow in the eastern, southeastern, and western directions and walruses showed no directional tendencies. In the southern region, ice moved primarily in the southern, southwestern, and western directions and walruses showed no directional tendencies. In the eastern region, ice tended to flow to the south and walruses tended to move to the north. In the western region, ice tended to flow in the southeastern, southwestern, and northwestern directions and walruses moved mostly in the northwestern, eastern, and southeastern directions.

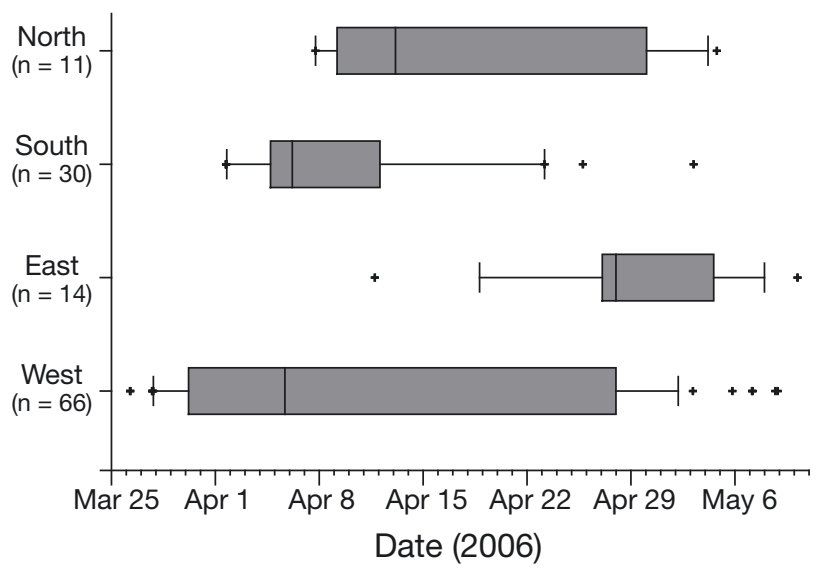

Fig. 2. Odobenus rosmarus divergens. Starting date of walrusice vector pairs observed in 4 regions of the northern Bering Sea, 26 March to 10 May 2006. Outliers (+) and the 25th, 50th, 75th (box), and 10th and 90th (whiskers) percentiles are indicated. $\mathrm{n}$ : number of walrus-ice vector pairs

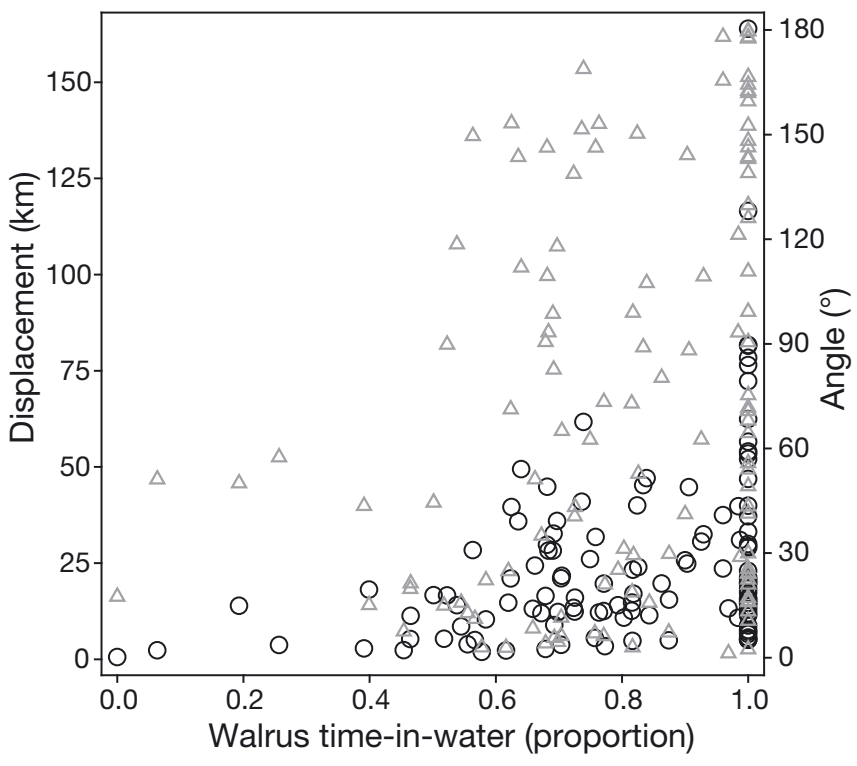

Fig. 3. Odobenus rosmarus divergens. Walrus-ice vector pair angle $(\triangle)$ and displacement $(O)$ and associated walrus timein-water observed in the northern Bering Sea, 26 March to 10 May 2006 
The rates of ice movements were also highly variable (Fig. 5), but were comparatively slow in the northern region and fast in the eastern region, which is consistent with general descriptions of ice motion within the Bering Sea (Burns et al. 1981). Rates of walrus movements were somewhat slower in the northern region than in the other 3 regions.

Variance of walrus-ice vector pair angles increased approximately in proportion to their mean, as suggested by the plot of angle versus walrus time-in-water (Fig. 3). Examination of residuals indicated that this variance function was adequately fit with an over-dispersed
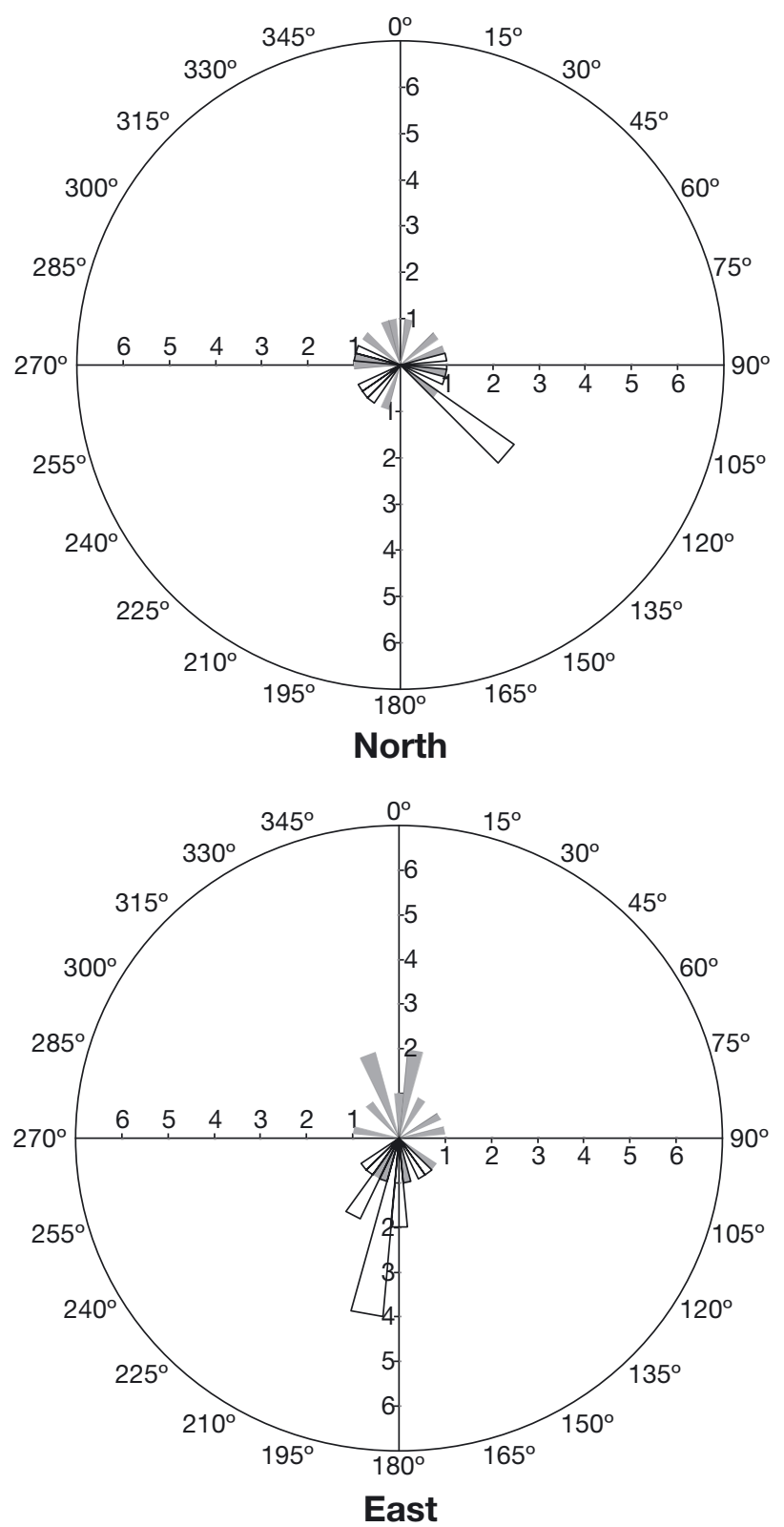

Poisson distribution. Over-dispersion was modeled by including the random effect of walrus (variance estimate $=0.46, \mathrm{SE}=0.17$ ). A plot of predicted versus observed angle indicated that a large proportion of the total variation in angle between walrus and ice vectors remained unexplained (Fig. 6). Nevertheless, the model indicated that angle increased with duration of the observation $\left(F_{1,95}=314.1, \mathrm{p}<0.01\right.$; Fig. 7$)$ and with the proportion of time the walrus spent in the water $\left(F_{1,95}=240.2\right.$, $\mathrm{p}<0.01)$. Least-squares mean estimates of vector pair angles ranged from $40^{\circ}$ to $81^{\circ}$ among regions (Table 3). Vector pair angles were similar in the northern and west-
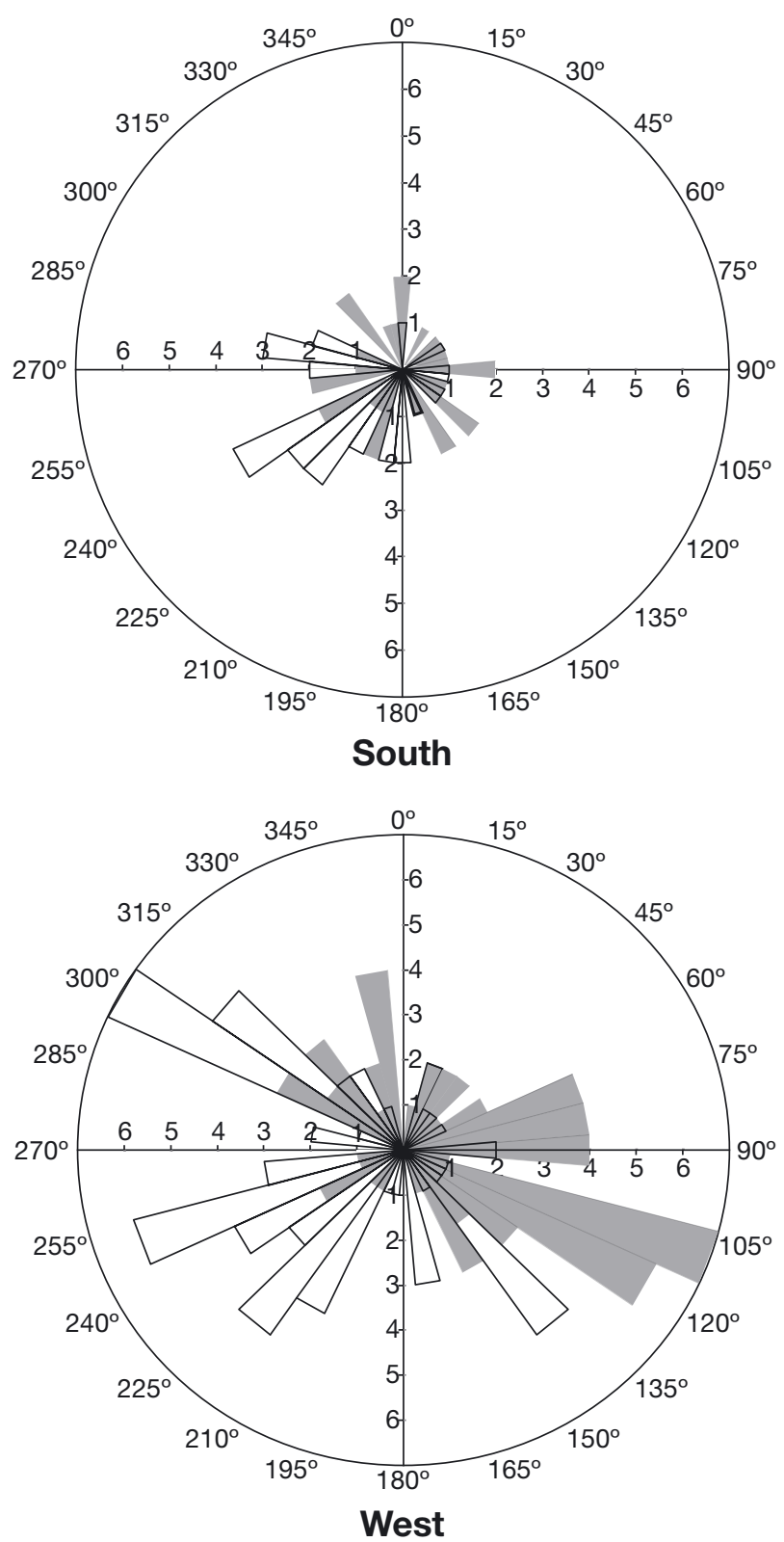

Fig. 4. Odobenus rosmarus divergens. Directions of walrus (solid bars) and sea ice (open bars) movements from walrus-ice vector pairs in 4 regions of the northern Bering Sea, 26 March to 10 May 2006. The length of a bar indicates the number of observations within that $10^{\circ}$ bin 


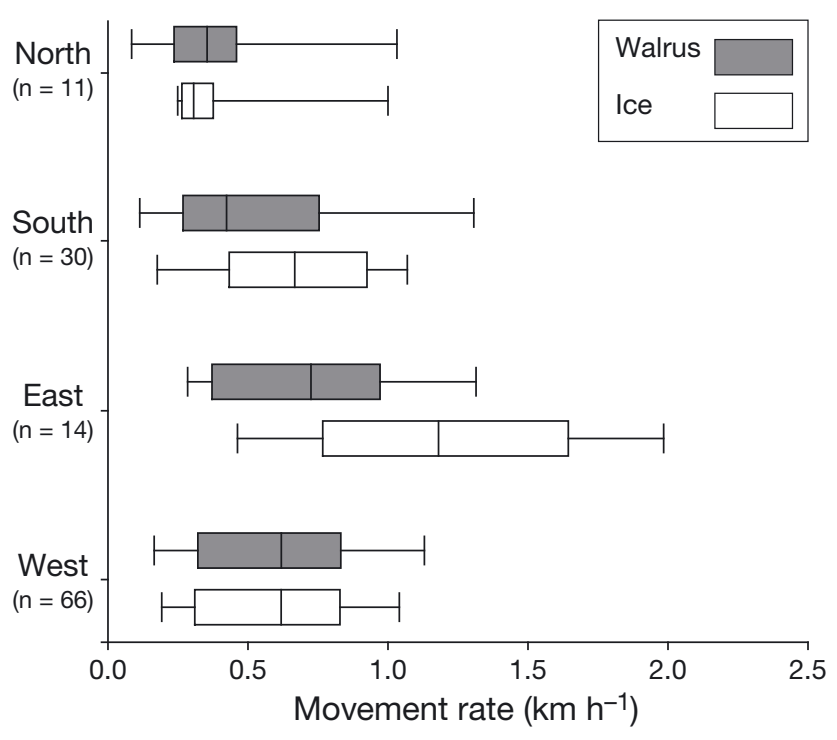

Fig. 5. Odobenus rosmarus divergens. Rates of walrus and sea ice movements from walrus-ice vector pairs in 4 regions of the northern Bering Sea, 26 March to 10 May 2006. The 25th, 50th, 75th (box), and 10th and 90th (whiskers) percentiles are indicated. $\mathrm{N}$ : number of walrus-ice vector pairs

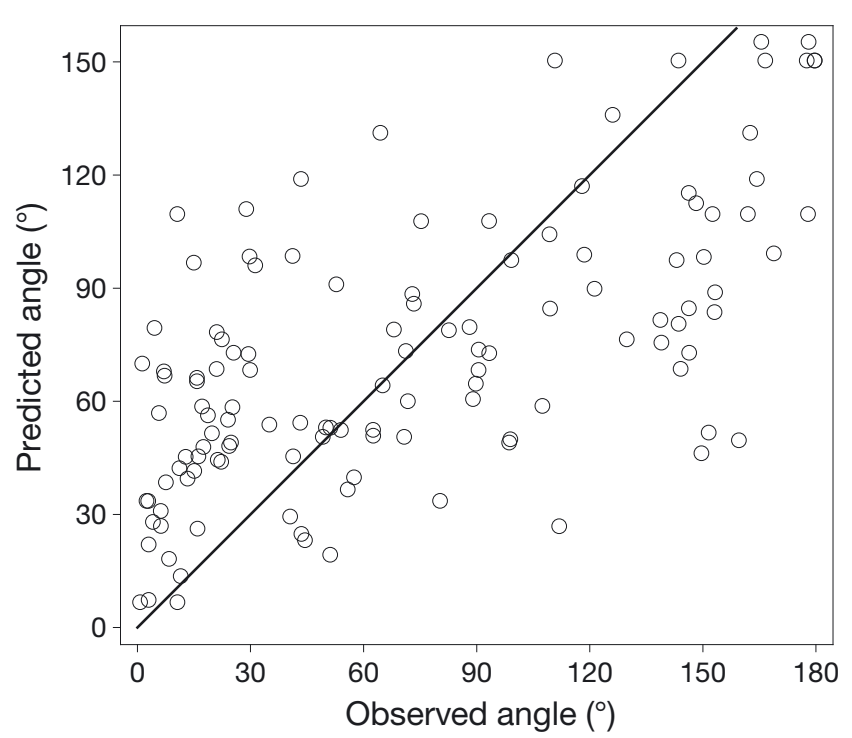

Fig. 6. Odobenus rosmarus divergens. Comparison of predicted and observed angles of walrus-ice vector pairs observed in the northern Bering Sea, 26 March to 10 May 2006. Predictions that exactly match observations would lie on the indicated $45^{\circ}$ line

ern regions, but tended to be larger in the southern (difference of least-squares means $\geq 32^{\circ}, 95 \% \mathrm{CI}=25-38$ ) and eastern (difference of least-squares means $\geq 39^{\circ}$, $95 \% \mathrm{CI}=31-48$ ) regions. Vector pair angles in the eastern region also tended to be larger than angles in the southern region (difference of least-squares means $=8^{\circ}$, $95 \%$ CI = 7-9) (Fig. 7, Table 3).

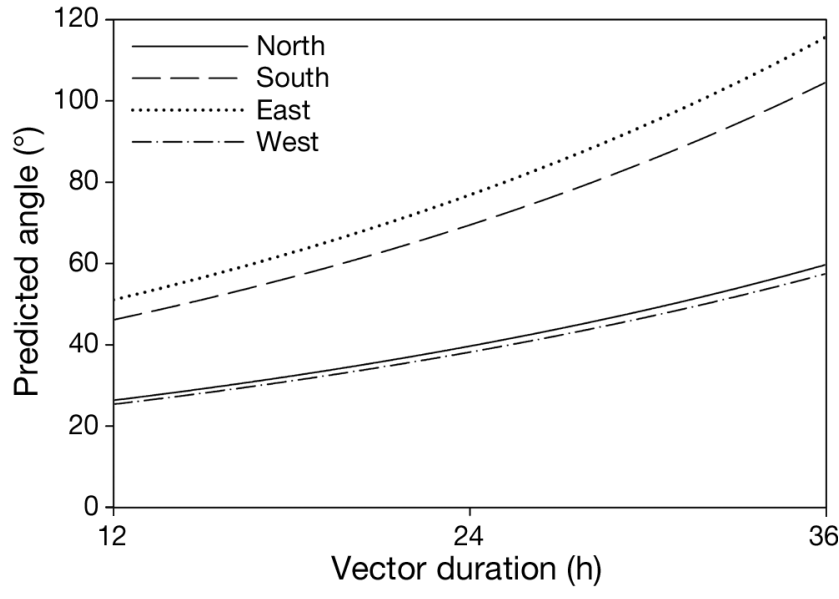

Fig. 7. Odobenus rosmarus divergens. Model predictions of angle of walrus-ice vector pairs observed in 4 regions of the northern Bering Sea, 26 March to 10 May 2006. Predictions are estimated for a walrus time-in-water value of 1.0

Table 3. Odobenus rosmarus divergens. Least-squares mean estimates of the angle and displacement of walrus-ice vector pairs observed in 4 regions of the northern Bering Sea, 26 March to 10 May 2006

\begin{tabular}{|c|c|c|c|c|}
\hline \multirow[t]{2}{*}{ Region } & \multicolumn{2}{|c|}{ Angle (degrees) } & \multicolumn{2}{|c|}{ Displacement $(\mathrm{km})$} \\
\hline & Mean & $95 \%$ CI & Mean & $95 \% \mathrm{CI}$ \\
\hline North & 42 & $30-58$ & 14.5 & $9.8-21.6$ \\
\hline South & 74 & $55-99$ & 21.9 & $17.2-28.0$ \\
\hline East & 81 & $60-111$ & 34.6 & $23.9-50.2$ \\
\hline West & 40 & $30-55$ & 20.3 & $17.2-23.8$ \\
\hline
\end{tabular}

Variance of walrus-ice vector pair displacements increased approximately with the square of their mean (Fig. 3). Examination of residuals indicated that this variance function was adequately fit with a gamma distribution. The estimate of the variance component associated with the random walrus effect converged to zero, so we eliminated it from the final model. As with the model for angles, the final gamma model for displacements left a large amount of variation unexplained (Fig. 8), but it indicated that displacement increased with duration of the observation $\left(F_{1,117}=\right.$ 29.7, p $<0.01$; Fig. 9) and with the proportion of time the walrus spent in the water $\left(F_{1,117}=35.1, \mathrm{p}<0.01\right)$, and that there were differences among regions (Table 3). Least-squares mean estimates of vector pair displacements ranged from 15 to $35 \mathrm{~km}$ among regions (Table 3). Vector pair displacements tended to be larger in the eastern than in the northern (difference of least-squares means $=20.1 \mathrm{~km}, 95 \% \mathrm{CI}=9.2-31.0$ ), southern (difference of least-squares means $=12.7 \mathrm{~km}$, $95 \% \mathrm{CI}=7.0-18.4$ ), and western (difference of leastsquares means $=14.4 \mathrm{~km}, 95 \% \mathrm{CI}=8.6-20.1$ ) regions (Fig. 9, Table 3). 


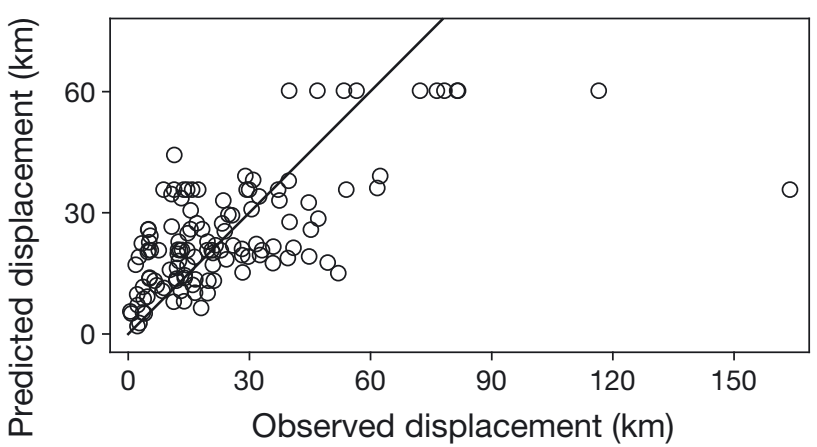

Fig. 8. Odobenus rosmarus divergens. Comparison of predicted and observed displacement of walrus-ice vector pairs observed in the northern Bering Sea, 26 March to 10 May 2006. Predictions that exactly match observations would lie on the indicated $45^{\circ}$ line

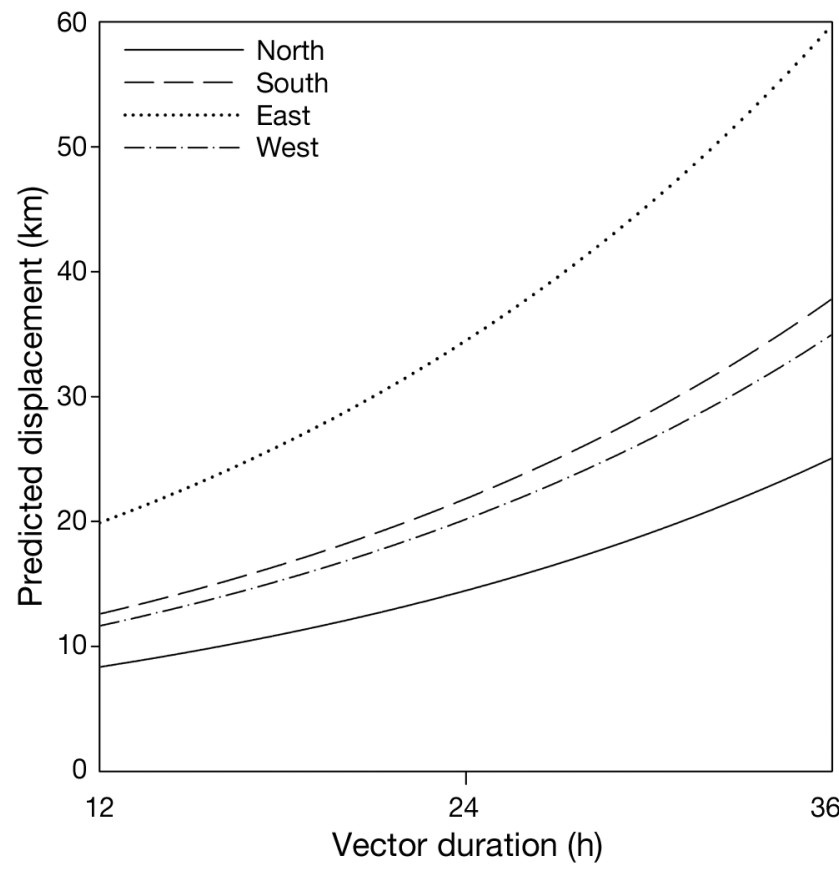

Fig. 9. Odobenus rosmarus divergens. Model predictions of displacement of walrus-ice vector pairs observed in 4 regions of the northern Bering Sea, 26 March to 10 May 2006. Predictions are estimated for a walrus time-in-water value of 1.0

\section{DISCUSSION}

We observed substantially divergent movement (angle and displacement) between walruses and their initially associated ice floes in all 4 regions of the study area. The magnitude of divergence varied among regions, which can be attributed to regional differences in the direction and rate of walrus and ice movements.

The longer a walrus is in water, the more it can diverge from the movements of ice, which was reflected in our study by increased divergence with duration of observation and walrus time-in-water. The rate and direction of walrus movements are probably associated with the type of activity in which the animal is engaged, an association observed in other marine mammals (Austin et al. 2004). In-water movements may be limited in some areas by thick and highly concentrated ice.

The period of our observations (26 March to 10 May) corresponds to a period from very early spring (when most walruses are still within their winter breeding areas [post-breeding]) to late spring (when walruses are migrating as the ice disintegrates). Other behaviors that walruses are engaged in during this period include calving (starting mid-April), foraging, and potentially, avoidance of subsistence hunting (Fay 1982). Since most tagged walruses were non-parturient adult females, most of the walruses in our study were likely engaged in behaviors related to familial social interactions, migration, and foraging.

The comparatively low walrus-ice divergence we observed in the northern region was associated with low rates of both walrus and sea ice movements. Although this region is characterized by having strong northward water currents (Danielson et al. 2006), the walruses did not show a strong tendency to travel north. Their movement may have been inhibited by difficulty in traveling amongst highly compressed ice, another characteristic of this region (Burns et al. 1980).

The relatively moderate walrus-ice divergence we observed in the southern region was associated with moderate rates of ice movements tending between the south and west, coupled with similar rates of walrus movements with no directional tendencies. Presumably, water currents in this region had little influence on walrus movement, since the area where most of our observations were made had only weak nearshore currents (Danielson et al. 2006).

The comparatively high walrus-ice divergence we observed in the eastern region was associated with comparatively high rates of southward ice drift and the tendency for walruses to move northward. Most of our observations in the eastern region were made from late-April through mid-May, a time when walruses are typically migrating northward, primarily by swimming (Fay 1982). Given the strong northward currents described for the central and northern areas of this region (Danielson et al. 2006), water currents may have contributed to the walruses' northward progression.

The relatively moderate walrus-ice divergence we observed in the western region was associated with moderate rates of ice movements tending from the southeast to northwest, and walrus movements tending from the northwest to southeast. As in the southern region, many of our observations in the southern part 
of the western region were within the area of the nearshore band of weak flowing currents, and therefore walrus movements there were not likely to have been aided much by water currents. However, the strong water currents flowing northward through the central portion of this region (Anadyr Strait) (Danielson et al. 2006) may have aided in the northward progression of some walruses.

We recognize that our analyses included measurement error associated with Argos location estimates for walruses. However, the magnitude of the walrus and ice displacements were typically larger than those attributable to Argos measurement errors alone. The non-zero value for angle and displacement for the case when a walrus was hauled out on ice during the entire observation (i.e. walrus time-in-water $=0$, Fig. 3) was the result of measurement errors. These measurement errors would include those associated with Argos walrus location estimates and relatively small spatial errors introduced from the inexact temporal match of walrus and ice floe locations.

We also recognize that the regions we used to assign walrus-ice vectors are rough approximations to ice habitat boundaries that occurred during our study. These boundaries probably shifted somewhat from short-scale fluctuations in ice drift. Although the net transport of ice is southward during winter and early spring, the rate and direction of drift are not uniform throughout the pack ice (Burns et al. 1981). Short-term (several days), small-scale fluctuations in ice drift occur, probably from variations in local winds, currents, and ice interactions (Muench \& Ahlnas 1976).

Ice over the continental shelf affords walruses the ability to exploit benthic prey over large areas. It has been recognized that when walruses rest on moving ice they can be transported to new feeding areas (Fay 1982). It has been further suggested that, on a local scale $(\sim 1$ to $100 \mathrm{~km})$, walruses 'home' to specific or neighboring ice floes to haul out after bouts of benthic foraging, and that the continuously moving floes determine the areal extent of foraging by walruses, thereby dispersing benthic predation (Ray et al. 2006).

However, we observed substantial divergence between walruses and their initially associated ice floes, suggesting that areas of walrus activities were independent of the movement of ice floes at a local scale. Furthermore, in several walrus-ice vector pairs, the walrus was hauled out at the beginning and end of the walrus vector. The average walrus-ice displacement of these vector pairs was $19 \mathrm{~km}(\mathrm{SD}=11 \mathrm{~km}, \mathrm{n}=7)$, suggesting also that walruses were not homing to specific ice floes between in-water bouts. Lack of correspondence between walrus and sea ice movements suggests that sea ice movements do not necessarily determine the extent of walrus foraging and may not prevent walruses from intensely feeding on local benthic prey. Local and regional heterogeneity in benthic biomass and community composition within our study area (Grebmeier et al. 2006) could lead walruses to preferentially select certain areas for foraging.

The magnitude of walrus-ice divergence may be partially dependent on the seasonal concentration and extent of useable ice. Although an extensive ice field was accessible to walruses during our study, in other places and times of year within the annual range of walruses, walrus-ice divergences may not occur to the same magnitude as we observed. For example, in the Chukchi Sea in late summer, ice extent over the continental shelf is sometimes reduced to very sparse ice (Jay \& Fischbach 2008). During these times, walruses may be limited in their movements to areas where these ice floes are available, and in these cases, their movements may be more congruent with the movement of ice floes than what we observed here.

Acknowledgements. We appreciate field assistance from Y. Bukhtiyarov, M. Cody, A. Grachev, E. Gurarie, A. Kochnev, N. Kutrukhin, E. Rypkhirgin, and G. Sheffield. We thank S. Speckman and S. DellaSilva who worked diligently to procure a contract with the Russian vessel RV 'Magadan' for walrus tagging. We thank the crew of the RV 'Magadan' for their professional seamanship and kind support. Aerial reconnaissance of walruses was provided by USFWS and Commander Northwest. V. Burkanov was instrumental in securing work boats and assuring the safe storage and transport of field gear from Russia. University of Alaska Fairbanks, Alaska Satellite Facility kindly facilitated the availability of SAR imagery. K. Oakley, P. Boveng, D. Atwood, and 4 anonymous reviewers provided helpful comments on earlier versions of the manuscript. Funding and administrative support was provided by the US Fish \& Wildlife Service, Marine Mammals Management Office, Anchorage, and the US Geological Survey, Alaska Science Center. Additional funding was provided by the North Pacific Research Board to complete analyses of SAR imagery. Walrus tagging was conducted under USFWS Permit No. MA801652-3. Any mention of trade names is for descriptive purposes only and does not constitute endorsement by the federal government.

\section{LITERATURE CITED}

Andrews RD, Pitman RL, Ballance LT (2008) Satellite tracking reveals distinct movement patterns for Type $\mathrm{B}$ and Type $\mathrm{C}$ killer whales in the southern Ross Sea, Antarctica. Polar Biol 31:1461-1468

Austin D, Bowen WD, McMillan JI (2004) Intraspecific variation in movement patterns: modeling individual behaviour in a large marine predator. Oikos 105:15-30

Born EW, Rysgaard S, Ehlme G, Sejr M, Acquarone M, Levermann N (2003) Underwater observations of foraging freeliving Atlantic walruses (Odobenus rosmarus rosmarus) and estimates of their food consumption. Polar Biol 26:348-357

Burns JJ, Shapiro LH, Fay FH (1980) The relationships of marine mammal distributions, densities, and activities to sea ice conditions. Environmental assessment of the Alaskan continental shelf. Final Reports of Principal In- 
vestigators. Biological Studies Vol 2. NOAA, US Dept Commerce

Burns JJ, Shapiro LH, Fay FH (1981) Ice as marine mammal habitat in the Bering Sea. In: Hood DW, Calder JA (eds) The eastern Bering Sea shelf: oceanography and resources. University Washington Press, Seattle, p 781-797

Collecte Localisation Satellites (2007) Argos user's manual. Collecte Localisation Satellites, Ramonville-Saint-Agne, France

Danielson S, Aagaard K, Weingartner T, Martin S, Winsor P, Gawarkiewicz G, Quadfasel D (2006) The St. Lawrence polynya and the Bering shelf circulation: new observations and a model comparison. J Geophys Res 111:C09023 doi:10.1029/2005JC003268

Douglas DC (2006) The Douglas Argos-Filter, Version 7.03. Available from http://alaska.usgs.gov/science/biology/ spatial/douglas.html

Eckert SA, Moore JE, Dunn DC, van Buiten RS, Eckert KL, Halpin PN (2008) Modeling loggerhead turtle movement in the Mediterranean: importance of body size and oceanography. Ecol Appl 18:290-308

Fay FH (1982) Ecology and biology of the Pacific walrus, Odobenus rosmarus divergens Illiger, Vol 74. US Dept Interior, Fish and Wildlife Service, Washington, DC

Fay FH, Kelly BP (1989) Development of a method for monitoring the productivity, survivorship, and recruitment of the Pacific walrus population. Final Report, OCSEAP Study MMS 89-0012. Minerals Management Service, Anchorage, Alaska

Fischbach AS, Jay CV, Jackson JV, Andersen LW, Sage GK, Talbot SL (2008) Molecular method for determining sex of walruses. J Wildl Manag 72:1808-1812

Fisher NI (1993) Statistical analysis of circular data. Cambridge University Press, New York, NY

Freitas C, Lydersen C, Fedak MA, Kovacs KM (2008) A simple new algorithm to filter marine mammal Argos locations. Mar Mamm Sci 24:315-325

Grebmeier JM, Cooper LW (1995) Influence of the St. Lawrence Island polynya upon the Bering Sea benthos. J Geophys Res 100:4439-4460 doi:10.1029/94JC02198

Grebmeier JM, Cooper LW, Feder HM, Sirenko BI (2006) Ecosystem dynamics of the Pacific-influenced northern Bering and Chukchi Seas in the Amerasian Arctic. Prog Oceanogr 71:331-361

Jay CV, Fischbach AS (2008) Pacific walrus response to Arctic sea ice losses, US Geological Survey Fact Sheet 20083041, US Geological Survey, US Dept Interior. Available at http://pubs.usgs.gov/fs/2008/3041/pdf/fs20083041.pdf

Jay CV, Hills S (2005) Movements of walruses radio-tagged in Bristol Bay, Alaska. Arctic 58:192-202

Editorial responsibility: Hans Heinrich Janssen, Oldendorf/Luhe, Germany
Jay CV, Heide-Jørgensen MP, Fischbach AS, Jensen MV, Tessler DF, Jensen AV (2006) Comparison of remotely deployed satellite radio transmitters on walruses. Mar Mamm Sci 22:226-236

Kwok R (1998) The RADARSAT geophysical processor system. In: Tsatsoulis C, Kwok R (eds) Analysis of SAR data of the polar oceans: recent advances. Springer, New York, NY, p 235-257

Littell RC, Milliken GA, Wolfinger RD, Schabenberger O (2006) SAS for mixed models. SAS Press, Cary, NC

> Maslanik JA, Fowler C, Stroeve J, Drobot S, Zwally J, Yi D, Emery W (2007) A younger, thinner Arctic ice cover: increased potential for rapid, extensive sea-ice loss. Geophys Res Lett 34:L24501 doi:10.1029/2007GL032043

McCullagh P, Nelder JA (1999) Generalized linear models, 2nd edn. Chapman \& Hall, Boca Raton, FL

Metcalf V, Robards M (2008) Sustaining a healthy humanwalrus relationship in a dynamic environment: challenges for comanagement. Ecol Appl 18:S148-S156

Muench RD, Ahlnas K (1976) Ice movement and distribution in the Bering Sea from March to June 1974. J Geophys Res 81:4467-4476 doi:10.1029/JC081i024p04467

Nelson CH, Johnson KR (1987) Whales and walruses as tillers of the sea floor. Sci Am 256:112-117

Nelson CH, Johnson KR, Barber JH (1987) Gray whale and walrus feeding excavation on the Bering Shelf, Alaska. J Sediment Petrol 57:419-430

Nelson CH, Phillips RL, McRea J Jr, Barber JH Jr, McLaughlin MW, Chin JL (1994) Gray whale and Pacific walrus benthic feeding grounds and sea floor interaction in the Chukchi Sea OCS study. Alaska Outer Continental Shelf Region of Minerals Management Service, US Dept Interior, Anchorage, $\mathrm{AK}$

Oliver JS, Slattery PN, O'Connor EF, Lowry LF (1983) Walrus, Odobenus rosmarus, feeding in the Bering Sea: a benthic perspective. Fish Bull 81:501-512

Oliver JS, Kvitek RG, Slattery PN (1985) Walrus feeding disturbance: scavenging habits and recolonization of the Bering Sea benthos. J Exp Mar Biol Ecol 91:233-246

> Overland JE, Wang M (2007). Geophys Res Lett 34:L17705 doi:10.1029/2007GL030808

Ray GC, McCormick-Ray J, Berg P, Epstein HE (2006) Pacific walrus: benthic bioturbator of Beringia. J Exp Mar Biol Ecol 330:403-419

Stroeve J, Holland MM, Meier W, Scambos T, Serreze M (2007) Arctic sea ice decline: faster than forecast. Geophys Res Lett 34:L09501 doi:10.1029/2007GL029703

> Wang M, Overland JE (2009) A sea ice free summer Arctic within 30 years? Geophys Res Lett 36:L07502 doi:10.1029/ 2009GL037820

Submitted: April 3, 2009; Accepted: March 9, 2010

Proofs received from author(s): May 7, 2010 